\title{
Relationship between dental plaque formation and salivary cortisol level in pregnant women
}

\section{Purpose}

Understanding how increased level of salivary cortisol contributes to the development of dental biofilm during pregnancy can help inthe prevention of dental caries and periodontal diseases. This study aims to evaluate the relationship between salivary cortisol level and dental biofilm formation in pregnant women.

\section{Patients and Methods}

This descriptive-analytic study was conducted in Hamadan, Iran in 2011. Forty consecutive pregnant women with no history of abortion, stillbirth, or any known physical or psychological disorders at weeks 25 and 33 of gestation were included. Salivary samples were collected for measurement of cortisol levels by Enzyme Linked Immunoabsorbent Assay (ELISA) method. The amount and extension of dental biofilms were determined by using a disclosing agent. Data were analyzed using descriptive and analytical statistics in SPSS version 16

\section{Results}

The mean levels of salivary cortisol at weeks 25 and 33 of gestation were respectively, $2.45 \pm 1.56 \mu \mathrm{g} / \mathrm{dl}$ and $5.24 \pm 4.07 \mu \mathrm{g} / \mathrm{dl}$ which demonstrates a significant difference $(\mathrm{P}<0.001)$. Evaluation of dental biofilm at two time intervals revealed a significant increase in amount of dental biofilm at week 33 of gestational period $(34.65 \pm 10.9 \%$ vs. $42.45 \pm 12.35 \%, P<0.001)$. Elevated levels of dental biofilm were significantly correlated with salivary cortisol levels at week $33(r=0.494, \mathrm{P}=0.001)$, however, it was not significant at week 25 of gestation $(r=0.148, P=0.361)$.

\section{Conclusion}

The findings suggested that increased levels of salivary cortisol can predict dental biofilm formation and accumulation in pregnant women in the last weeks of gestation.

Keywords: Cortisol; dental; plaque; biofilm; saliva; pregnancy

\section{Introduction}

It has been proven that changes occur in oral cavity and stomatognatic system during pregnancy which may lead to the periodontal disease, dental caries, oral mucosal changes, chloasma, tooth loosening and erosion (1-3). Although it has been suggested that poor oral health is the most important reason for these oral complications, some other causes including physiological and hormonal changes particularly in saliva during this period may lead to these oral diseases (4). In this context, significant hormonal changes occur in pregnant women that can directly affect the salivary hormones.

Stressful conditions within pregnancy can be induced by increased levels of cortisol and lead to decreased number of IgA and IgG antibodies which supports the growth of oral bacteria and the occurrence of local

\author{
Azita Tiznobaik ${ }^{1,2}(\mathbb{D}$, \\ Safoura Taheri ${ }^{3}$ (D), \\ Parviz Torkzaban ${ }^{4}$ (D), \\ Ali Ghaleiha ${ }^{5}$ (1), \\ Ali Reza Soltanian ${ }^{6}$ (D), \\ Reza omrani ${ }^{7}$ (D), \\ Mehdi Shirinzad? ${ }^{7}$
}

ORCIDIDs of the authors: A.T. 0000-0002-5220-9442 S.T. 0000-0002-6837-4020; P. 0000-0003-4933-7520; A.G. 0000-0003-3037-2676; A.R.S. 0000-0002-7483-3502; R.0.0000-0003-4077-7132; M.S. 0000-0003-2455-9653

'Department of Reproductive Health, Faculty of Nursing and Midwifery, Tehran University of Medical Sciences, Tehran, Iran

${ }^{2}$ Department of Midwifery, Maternity and Child Care Research Center, Faculty of Nursing and Midwifery, Hamadan University of Medical Sciences, Hamadan, Iran

${ }^{3}$ Department of Midwifery, Faculty of Nursing and Midwifery, Ilam University of Medical Sciences, Ilam, Iran

${ }^{4}$ Department of Periodontics, Faculty of Dentistry, Hamadan University of Medical Sciences, Hamadan, Iran

${ }^{5}$ Research center for Behavioral disorders and substance abuse, Hamadan University of Medical Sciences, Hamadan.

Iran

${ }^{6}$ Modeling of non-communicable diseases research center, school of public health, Hamadan University of Medical science, Hamadan. Iran.

Department of Restorative Dentistry, Faculty of Dentistry, Hamadan University of Medical Sciences, Hamadan, Iran

Corresponding Author: Mehdi Shirinzad E-mail: shirinzad2000@gmail.com

Received: 14 November 2017 Revised: 17 April 2018 Accepted: 10 May 2018

DOI: 10.26650/eor.20192484 
inflammation (5). Although the mechanisms of stress and dental plaque formation are not clear, stress may reduce individual resistance to dental disease causing bacteria. These microorganisms produce inflammatory and immune responses in the host tissue $(6,7)$. Corticosteroids released during stress impede the immune response, which inhibits salivary immunoglobulins (especially $\lg A$ ) and other antimicrobial proteins present in the saliva such as lactoferrin, lysozyme and lactoperoxidase. Catecholamines can have a direct effect on plasma cells by reducing the synthesis of secretion of immunoglobulin A. Simultaneous changes in the quality and quantity of saliva may lead to increased adherence capability and production of biofilm on dental surfaces and increased sensitivity to decay (8).

As dental biofilm causes tooth decay and periodontal disease,it is one of the most important indicators of the clinical progress of both condition (9). Studies in different groups such as children and women, have shown a positive association between cortisol and dental biofilm (10-13). However, Kambalimathet al. (14) who had investigated 4- to 5-year-old children, reported that no correlation between cortisol and dental biofilm can be found. Considering these conflicting arguments in the relationship between cortisol and dental biofilm, the importance of oral health during pregnancy, we aimed to investigate possible relationship between dental biofilm formation and cortisol levels in pregnant women. The null hypothesis tested in this study is that there is no correlation between biofilm formation and salivary cortisol levels in any examined period of pregnancy.

\section{Patients and Methods}

\section{Sample characteristics}

40 pregnant women were included in this cross-sectional study with simple sampling, which has been conducted in Hamadan, Iran, 2011. Inclusion criteria were nulliparous, gingival Index<1 (15) and Beck anxiety test $<19$ (16). Exclusion criteria were history of abortion, stillbirth, gestational diabetes, any known physical or psychological disorder, smoking and unwanted pregnancy. Also, subjects had to be between 18 and 35 years of age and had to have complete recorded data at the institutional healthcare centers. Pregnant women at week 25 of gestation who were experiencing their first pregnancy under normal sociologic and behavioral conditions were enrolled and they signed the informed consent approved by Institutional Ethics Committee (Ethic code: IR.UMSHA.REC.1396.428) at Hamadan University of Medical Sciences, Iran.

\section{Sample size calculation}

Based on previous studies, if the standard deviation of cortisol levels and salivary growth in pregnant women is considered to be about 0.45 , then the minimum difference between cortisol groups is 0.3 . When the an error level is 0.05 and the poweris $90 \%$, the minimum number of subjects required per group was calculated as 38 which was rounded up to 40 for practical purposes.

Studies have shown that cortisol level increases between
25-33 weeks of pregnancy (17). After obtaining informed consent, in the first stage, all subjects were examined by one periodontist to determine gingival index in $25^{\text {th }}$ week of pregnancy and rule out gestational diabetes by OGGT Test. Also, Beck Stress Test was performed by one psychologist. Subjects with gingival index $>1$ and Beck Stress Test $\geq 19$ were excluded. At stage two, after 8 weeks, all participants were invited to healthcare centers and were reexamined in terms of amount and extension of dental biofilms and collection of second salivary samples to measure their salivary cortisol level.

\section{Determination of gingival index}

Gingival Index was considered for the assessment of gingival condition. It is scored on the basis of 0.0 to 3.0. The score 0.0 means normal gingiva; 1.0 means mild inflammation or slight change in color and slight edema but no bleeding on probing; 2.0 means moderate inflammation or redness, edema and glazing, bleeding on probing, and score 3.0 means severe inflammation or marked redness and edema, ulceration with tendency to spontaneous bleeding. The bleeding was assessed by probing gently along the wall of soft tissue of gingival sulcus. The scores of four areas of the tooth were summed and divided by four to give the gingival index for tooth (15).In our study, mothers with a score of over 1 were identified as being infected and excluded from the study.

\section{Performance of Beck stress test}

A questioner consisting of twenty-one questions that expressed common symptoms of stress and anxiety. Each question has the same set of four possible answer choices including; not at all (Score 0.0), mildly (Score 1.0), moderately (Score 2.0), and severely (Score 3.0) (18).

\section{Determination of salivary cortisol level}

This examination was carried out by Enzyme Linked Immunosorbent Assay (ELISA) method using commercial saliva cortisol kit produced by Germany. Forty selected participant's saliva samples were collected from each case based on the standard protocol that was described by Dr. Navazesh (19) to determine levels of salivary cortisol. In this method, saliva samples were collected by expectoration between 9 a.m. and 11 a.m. to avoid circadian variation. Participants were asked to avoid eating, drinking, and brushing for at least 2 hours. The saliva sample was poured over the first minute and the saliva sample of fifth minute was collected. Saliva was collected in a laboratory plastic container and transferred to the laboratory within 2 hours of sampling.

\section{Determination of dental biofilm}

Dental biofilm is the most important cause of gum and periodontal disease. Microbial plaque is a thin layer of germs that constantly sit on the surface of the teeth and is contained in the mouth of all adults. This layer has protein substances and Coverage cells and other substances of salivary origin, but its main building is from microbes, so plaque control is 
one of the key components in dentistry. It is difficult to find a dental plaque. Normally, microbial plaque is not visible. Therefore, for observation, disclosing agentsare used as chemical pills that can stain dental plaque. The participants received disclosing agent and were asked to chew the disclosing tablet and use language gestures by rubbing the tablet on the tooth surface. Then the tonality of the tooth was determined in facial, lingual, distofacial and mesiofacial surfacesand calculated according to the formula of Sillness \& Loe (15).

\section{Statistical analysis}

Data were analyzed by descriptive (frequency distribution, percentage, and mean) and analytical statistics (paired T test, Pearson's Correlation Coefficient and Z-Fisher's correlation coefficient Test) using SPSS version 16 software (SPSS Inc. Released 2007. SPSS for Windows, Version 16.0. Chicago, IL, USA). Confidence level was set to $95 \%$ and the probability values $p \leq 0.05$ were considered statistically significant.

\section{Results}

The mean age of participants was $23.65 \pm 4.58$ years. Regarding the socioeconomic status, all women were housewives, $7.5 \%$ were illiterate, $25.0 \%$ had primary education level, 52.5\% had secondary education level, $12.5 \%$ had diploma, and only $2.5 \%$ had college degree. Also, $15.0 \%$ of women were categorized as low-economic and financial level, $67.5 \%$ as moderate economic level, and only $17.5 \%$ had appropriate economic level. Most of the women (95.0\%) did not refer to dentist for periodical dental evaluation. With respect to dental health cares, $72.5 \%$ followed daily tooth brushing and $22.5 \%$ brushed twice a day and only $5 \%$ used both tooth brushing and dental floss. KolmogorovSmirnov Test showed that all variables followed a normal distribution.Paired T Test showed that the mean level of salivary cortisol was found to be significantly higher at week 33 of gestation than week 25 (5.24 44.07 versus 2.45 $\pm 1.56 \mu \mathrm{g} / \mathrm{dl}, \mathrm{P}<0.001$ ) (Table 1 ). Also, evaluation of dental biofilm at two time points revealed a significant increase in the amount of dental biofilm at week 33 of gestation compared to week 25 (42.45 \pm 12.35 versus $34.65 \pm 10.9 \%$ $\mathrm{P}<0.001)$. Pearson's correlation coefficient analysis showed a positive correlation between salivary cortisol level and amount of dental biofilm at week 33 of gestation ( $r=0.494$, $\mathrm{P}=0.001)$, whereas this correlation was not statistically significant at week 25 of gestation $(r=0.148, P=0.361)$. In addition, Z-Fisher's correlation coefficient analysis showed that increased salivary cortisol level caused increase in the amount of dental biofilm ( $r=0.462, \mathrm{P}=0.001)$.

\section{Discussion}

The aim of present study was determining the correlation between dental biofilm accumulation and salivary cortisol level during gestational period. The findings depicted that increased levels of salivary cortisol were directly associated with the level of dental biofilm in pregnancy. This is in line with the notion that high levels of salivary cortisol can provide the conditions in favor of pathogen-induced plaque formation (20). The results of our study were similar to those of Johansson et al. (13). In this study, 72 women (29 controls with a mean age of 54 years without disease, and 43 subjects with mental discomfort with a mean age of 42 years) were studied in order to find out the relationship between salivary cortisol and dental plaque and gingivitis. The mean cortisol in the study group was $3.25 \pm 3.46$ and in the control group $0.25 \pm 0.30$. After measuring the dental plaque, the mean of this was higher in the study group. $(p=0.003)(13)$. In agreement with these data, Hugo et al, demonstrated that stress and salivary cortisol are significant risk indicators of plaque formation among individuals aged 50 years and older (21). But Kambalimath et al's study (14) found that there was no significant difference between case and control groups in terms of dental caries and stress in children. It seems that the main reason for the difference in the results of present study and Kambalimath et al's study (14) is that 1) stress as a phenomenon caused by the psychological and social pressures on the individual, is less effective in children, 2) children's dental checkup is not necessarily stressful, 3) and the process of dental caries is longer than the formation of dental biofilm.

A trilateral relation is suggested between stress, oral immunity, and microbial activity. Stressful conditions compromise oral immunity, as indicated by decreased levels of salivary immunoglobulin and salivary flow and increased microbial activity (22). It has been demonstrated that stressful conditions such as pregnancy are associated with elevated cortisol level $(20,21)$. Increased levels of blood and salivary cortisol had been shown during pregnancy because of gestational stress and decrease in glomerular filtration rate particularly after week 25 of pregnancy. In this regard, some studies indicated that high salivary cortisol levels were associated with periodontal disorders and these stress-induced periodontal diseases could be due to changes in immunological responses to periopathogens $(20,22)$. Our study is among the first studies that have reported an association between salivary cortisol and dental biofilm formation during pregnancy, hence this result should be interpreted with caution.

Findings suggested that increased levels of salivary cortisol can predict dental biofilm formation. Increase in salivary cortisol

Table 1: Salivary cortisol level and dental biofilm at 25 and 33 weeks of gestation (*paired t test).

\begin{tabular}{lcccr} 
Variable & Minimum & Maximum & Mean \pm SD & P value * \\
\hline Cortisol level (25 week) & $0 \mu \mathrm{g} / \mathrm{dl}$ & $6.7 \mu \mathrm{g} / \mathrm{dl}$ & $2.45 \pm 1.56$ & 0.000 \\
\hline Cortisol level (33 week) & $0.5 \mu \mathrm{g} / \mathrm{dl}$ & $26 \mu \mathrm{g} / \mathrm{dl}$ & $5.24 \pm 4.07$ & 0.000 \\
\hline Dental biofilm (25 week) & $20 \%$ & $66 \%$ & $34.65 \pm 10.9$ & 0.000 \\
\hline Dental biofilm (33 week) & $21 \%$ & $72 \%$ & $42.45 \pm 12.35$ & 0.000 \\
\hline
\end{tabular}


levels as a sign of prenatal stress is associated with dental biofilm formation particularly at week 33 of gestation. Although it needs to be confirmed by further studies using larger sample sizes and specifically by evaluating salivary immune markers in relation to periodontal disorders in pregnant women. Our study had limitations, we examined only one hormone which, if one or more of the other hormones were studied, could have a stronger judgment on our assumptions. As points of strength, in present study, the women with history of smoking, or those who have any evidence of gestational diabetes, psychological disturbances and other excluding criteria were excluded to eliminate potential effects of these confounders on dental biofilm formation.

\section{Conclusion}

Findings show a positive correlation between salivary cortisol and dental biofilm at week 33 of gestation. This finding is very important because health policy-makers should, with this correlation, endeavor to produce better plans for having less stress-induced maternal pregnancies because the risk of dental biofilm increases in pregnancy by increasing cortisol in stressed conditions. Because restoration of teeth during pregnancy is associated with some restrictions, especially in the third trimester, we may not be able to reduce the damaging effects of dental plaque and the prevention is better than cure.

Türkçe öz: Gebelerde tükürük kortizon seviyesi ile dental plak oluşumu arasindaki ilişkinin incelenmesi. Amaç:Tükürükkortizon düzeyinin gebelik sırasında dental biyofilmin gelişimine nasıl katkıda bulunduğunu anlamak, diş çürüğü ve periodontal hastalıkların önlenmesinde yardımcı olabilir. Bu çalışmada gebelerde tükürük kortizol düzeyi ile biyofilm oluşumu arasındaki ilişkinin değerlendirilmesi amaçlanmıştır. Hastalar ve yöntem: Tamamlayıcı-analitik çalışma ,2011 yılında Iran'ın Hamadan kentinde gerçekleştirilmiştir. Gebeliğin 25 ve 33 haftaları arasında bulunup kürtaj, ölü doğum veya bilinen herhangi bir fiziksel veya psikolojik bozukluk öyküsü bulunmayan 40 gebe kadın dahil edilmiştir. Tükürük örnekleri kortizol düzeyinin ölçülmesi için ELISA (enzyme linked immunoabsorbent assay) yöntemi ile incelenmiştir. Dental biyofilmin miktarı ve yoğunluğu bir belirleyici ajan kullanılarak belirlenip veriler Spss 16 paket programında tanımlayıcı ve analitik istatistik analizler kullanarak değerlendirilmiştir. Bulgular: Gebeliğin 25 ve 33 haftalarında ortalama tükürük kortizol düzeyleri sırasıyla $2.45 \pm 1.56 \mathrm{mg} / \mathrm{dl}$ ve $5.24 \pm 4.07 \mathrm{mg} / \mathrm{dl}$ idi. Bu farkın istatistiksel olarak anlamlı olduğu görülmüştür ( $p<0.001)$. İki ölçüm zamanı arasında dental biyofilm miktarında anlamlı bir artış

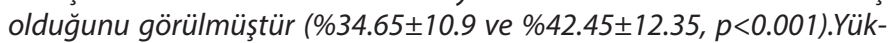
sek düzeydeki biyofilm, 33 haftada tükürük kortizol düzeyi ile ilişkili olduğu görülürken ( $r=0.494, p=0.001)$, gebeliğin 25 inci haftasında anlamlı ilişki görülmemiştir ( $r=0.148, p=0.361)$. Sonuç: Bulgular, gebeliğin son haftalarında tükürükte artmış kortizol düzeyinin, biyofilm oluşumu ve birikimini öngörebileceğini göstermektedir. Anahtar kelimeler: Kortizol; diş; plak; biofilm; tükürük; gebelik

Ethics Committee Approval: Ethics committee approval was received for this study from the ethics committee of Hamadan University of Medical Sciences (Ethic code: IR.UMSHA.REC.1396.428)

Informed Consent: Written informed consent was obtained from pregnant women who participated in this study.

Peer-review: Externally peer-reviewed.

Author contributions: AT and MS participated in designing the study. AT and PT participated in generating the data for the study. $\mathrm{RO}$ participated in gathering the data for the study. ARS participat- ed in the analysis of the data. RO and MS wrote the majority of the original draft of the paper. ST participated in writing the paper. All authors approved the final version of this paper.

Acknowledgements: This study was supported by the Hamadan University of Medical Sciences; the authors are grateful to the people who helped with this research.

Conflict of Interest: The authors have no conflicts of interest to declare.

Financial Disclosure: This research was funded by Hamadan University of Medical Sciences.

\section{References}

1. Barak $\mathrm{S}$, Oettinger $\mathrm{S}$, Barak O, Oetinger M. Common oral manifestations during pregnancy. A review. Obstet Gynecol Surv 2003;58(9):624-8. [CrossRef]

2. Cunnigham FG,Leveno KJ,Bloom SL, Hauth JC,Rouse DJ,Spong CY.Willams Obstetrics. 24th Ed. Mc Graw Hill Medical, New York; 2014. P.36-45.

3. Figuero E, Carrillo-de-Albornoz A, Martin C, Tobias A, Herrera D. Effect of pregnancy on gingival inflammation in systemically healthy women: a systematic review. J Clin Periodontol 2013;40(5):457-73. [CrossRef]

4. Mein L, Schmiot G, Martin C, Neumann I. Maternal cortisol in late pregnancy and hypothalamic pituitary adrenal reactivity to psychosocial stress postpartum in women. Stress 2010;13(2):16371. [CrossRef]

5. Khanna S, Shalini M . Pregnancy and oral health: forgotten territory revisited. Obstet Gynecol India 2010;60(2):123. [CrossRef]

6. Socransky SS, Haffajee AD. Dental biofilms: Difficult therapeutic targets. Periodontol 2000 2002;28:12-55. [CrossRef]

7. Williams RC. Periodontal disease. N Engl J Med 1990;322:373382. [CrossRef]

8. Morse DR, Schacterle GR, Furst ML, Goldberg J, Greenspan B, Swiecinski $D$, et al. The effect of stress and meditation on salivary protein and bacteria: A review and pilot study. J Hum Stress 1982;8:31-9. [CrossRef]

9. Newman MG, Takei HH, Klokkevold PR, Carranza FA. Carranza,s clinical periodontology. 12th Ed. Elsevier Saunders. Canada; 2015. P. 366-70.

10. Kandemir S, Oksan T, Alpoz A, Ergezer G, Salivary cortisol levels in children during dental treatment. J marmara univ dent fac 1997;2(4):639-42.

11. Rai k, Hedge A, Shetti S. Estimation of salivary cortisol in children with rampant caries. J clin pediater 2010;34(3):249-52. [CrossRef]

12. Fernando $N$, Juliano B, denis $R$, Tonantzin R, Josiane $p$, Maria D. Chronic stress, depression and cortisol levels as risk indicators of elevated plaque and gingivitis levels in individuals aged 50years and older, psychology institute 2007;77(6):1008-1013.

13. Johanson A, Rylander G, Soder B. Asberg A. Dental plaque, gingival inflammation, and elevated levels of interleukin -6 and cortisol in gingival cervicular fluid from women with stress-related depression and exhaustion. J periodontal 2006;77(8):1403-9. [CrossRef]

14. Kambalimath HV,Dixit VB,Tyyagi PS. Salivary cortisol response to psychological stress in children with early childhood caries. Indian dent res 2010;21(2):231-7. [CrossRef]

15. Newman MG, Takei HH, Klokkevold PR, Carranza FA. Carranza,s clinical periodontology. 12thEd. Elsevier Saunders. Canada; 2015. P. 366-70.

16. Beck AT, Epstein N, Brown G, Steer RA. An inventory for measuring clinical anxiety: psychometric properties. J Consult Clin Psychol 1988;56(6):893-7. [CrossRef]

17. Katie T, Kivlighan A, Janet A, Kathleen A, Markl. Diurnal rhythm of cortisol during late pregnancy. Psychoneuroendocrinology 2008;33:1225-1235. [CrossRef] 
18. Mona Basker, Prabhakar D Moses, Sushila Russell, and Paul Swamidhas Sudhakar Russell. The psychometric properties of beck depression inventory for adolescent depression in a primary-care paediatric setting in India. Child Adolesc Psychiatry ment Health 2007;1:8. Published online 2007, August 9. [CrossRef]

19. Navazesh M. How can oral health care provides determine if patient have dry mouth. J Am Dent Assoc 2003;134(5):613-20. [CrossRef]

20. Anna A, Echeverría A, Carolina M. Periodontitis and pregnancyAssociation between periodontitis in pregnancy and preterm or low birth weight: Review of the literature. Med Oral Patol Oral Cir Bucal 2008;13(9):609-15.
21. Hugo FN, Hilgert JB, Bozzetti MC, Bandeira DR, Gonçalves TR, Pawlowski Jet al. Chronic stress, depression, and cortisol levels as risk indicators of elevated plaque and gingivitis levels in individuals aged 50 years and older. J Periodontol 2006;77(6):100814. [CrossRef]

22. Raul I, Garcia A, Michellem H. Henshaw C, Elizabeth A. Relationship between periodontal disease and systemic health. J periodontology 2001;25(1):21-36. [CrossRef] 